\title{
Influence of Rare Earth Doping on Microstructure and Luminescence Behaviour of Sodium Sulphate
}

\author{
Y. S. Vidya and B. N. Lakshminarasappa \\ Department of Physics, Bangalore University, Jnana Bharathi Campus, Bangalore 560 056, India \\ Correspondence should be addressed to B. N. Lakshminarasappa; bnlnarasappa@rediffmail.com
}

Received 12 October 2013; Accepted 1 December 2013; Published 6 January 2014

Academic Editors: S. Binetti, F. Gourbilleau, and M. K. Jayaraj

Copyright (C) 2014 Y. S. Vidya and B. N. Lakshminarasappa. This is an open access article distributed under the Creative Commons Attribution License, which permits unrestricted use, distribution, and reproduction in any medium, provided the original work is properly cited.

\begin{abstract}
$\mathrm{Na}_{2} \mathrm{SO}_{4}, \mathrm{Na}_{2} \mathrm{SO}_{4}: \mathrm{Li}$, and $\mathrm{Na}_{2} \mathrm{SO}_{4}$ : $\mathrm{Li}$, Eu, Dy phosphors were prepared by using slow evaporation technique followed by subsequent calcination at $400^{\circ} \mathrm{C}$ for $4 \mathrm{~h}$. Doping with $\mathrm{Li}^{+}$ion stabilized the thenardite phase of host matrix, while codoping with $\mathrm{RE}^{3+}$ stabilized the phase transformation from stable thenardite to metastable mirabilite crystal structure. The microstructure and morphology were studied by using scanning electron microscopy and transmission electron microscopy. The thermoluminescence studies revealed that isovalent doping of $\mathrm{Li}^{+}$served as a quencher and addition of codopant introduces the additional trap sites in the host matrix. The room temperature emission spectra of Li-doped, $\mathrm{RE}^{3+}$-codoped, and undoped $\mathrm{Na}_{2} \mathrm{SO}_{4}$ were studied under ultraviolet radiation. For pure $\mathrm{Na}_{2} \mathrm{SO}_{4}$ the two peaks which appeared are at 364 and $702 \mathrm{~nm}$, respectively. The emission intensities of $\mathrm{RE}^{3+}$-codoped samples increase with increase in dopant concentration.
\end{abstract}

\section{Introduction}

Alkali sulphates have been known for a long time as versatile and excellent phosphor materials. These sulphates have attracted the attention of many workers in view of their potential applications in radiation dosimetry, TV screens, cathode ray tubes, and so forth. A variety of defect centres are likely to be formed in sulphate based phosphors [1-6]. Sulphate based radiation dosimeter materials doped with rare earth (RE) ions have been extensively investigated due to their high luminescence sensitivity [7]. Significant advancements have been made in thermoluminescence (TL) and photoluminescence (PL) experiments during the last couple of decades [8-10]. Up to date, sodium sulphate is extensively investigated from the prospect of phosphor material attributed to its simple chemical composition and defect rich crystal. $\mathrm{Na}_{2} \mathrm{SO}_{4}$ exhibits a variety of phase transitions between its five anhydrous polymorphs (labelled I$\mathrm{V})$. The phase transformation sequence among the $\mathrm{Na}_{2} \mathrm{SO}_{4}$ polymorphs can be described as

$$
\mathrm{V} \stackrel{473 \mathrm{~K}}{\longleftrightarrow} \mathrm{III} \stackrel{503 \mathrm{~K}}{\longleftrightarrow} \mathrm{II} \stackrel{510 \mathrm{~K}}{\longleftrightarrow} \mathrm{I} \stackrel{1156 \mathrm{~K}}{\longleftrightarrow} \text { Melt }
$$

$\mathrm{Na}_{2} \mathrm{SO}_{4}$ forms two naturally occurring minerals: mirabilite $\left(\mathrm{Na}_{2} \mathrm{SO}_{4} \cdot 10 \mathrm{H}_{2} \mathrm{O}\right)$ and thenardite $\left(\mathrm{Na}_{2} \mathrm{SO}_{4}\right)$. Both are in thermodynamic equilibrium at $32^{\circ} \mathrm{C}$ which may be lowered to $18^{\circ} \mathrm{C}$ in the presence of foreign ions [11]. At room temperature, phase $\mathrm{V}$ (thenardite) is reported to be stable while phase III is metastable. Phases I and II are high-temperature polymorphs; however, phase II is reported to have a narrow stability zone. Phase IV is considered to be metastable and its phase relation and structure have yet to be well established [12-15]. Correcher et al. [16] observed the spectra of infraredstimulated luminescence (IRSL), radioluminescence (RL), and TL of thenardite. Sidike et al. [17] studied the photoluminescence (PL) spectra, excitation spectra, and decay curves of natural, heat-treated, and $\gamma$-irradiated thenardite from Ai-Diang salt lake and concluded that crystal defects were responsible for observed luminescence. Reliable studies on the PL and TL properties of thenardite are very few till to date, to the best of our knowledge. In order to develop new dosimetric materials and to obtain a better understanding of the physical mechanism of radiation effects, $\mathrm{Na}_{2} \mathrm{SO}_{4}$ is doped and codoped with activators.

In the present work, fading TL and PL behaviour of pure and $\mathrm{RE}^{3+}$-codoped $\mathrm{Na}_{2} \mathrm{SO}_{4}$ matrix are explained in 
TABLE 1: The crystallite size and stress factor of pure, doped, and codoped $\mathrm{Na}_{2} \mathrm{SO}_{4}$ samples.

\begin{tabular}{|c|c|c|c|c|c|c|c|c|c|c|}
\hline \multirow{2}{*}{ Phosphor } & \multicolumn{2}{|c|}{ Crystallite size $(\mathrm{nm})$} & \multicolumn{2}{|c|}{ FWHM values (rad) } & \multicolumn{2}{|c|}{$d$ spacing $(\AA)$} & \multicolumn{2}{|c|}{$2 \theta$ (degrees) } & \multicolumn{2}{|c|}{ Stress factor $(\varepsilon) \times 10^{-3}$} \\
\hline & $\mathrm{T}$ & M & $\mathrm{T}$ & M & $\mathrm{T}$ & M & $\mathrm{T}$ & M & $\mathrm{T}$ & M \\
\hline $\mathrm{Na}_{2} \mathrm{SO}_{4}$ & 55 & - & 0.29 & - & 1.43 & - & 32.4 & - & 1.2 & - \\
\hline $\mathrm{Na}_{2} \mathrm{SO}_{4}: \mathrm{Li}_{0.5 \%}$ & 22 & - & 0.37 & - & 2.77 & - & 32.3 & - & 5.5 & - \\
\hline $\mathrm{Na}_{2} \mathrm{SO}_{4}: \mathrm{Li}_{0.5 \%}, \mathrm{Eu}_{0.5 \%}, \mathrm{Dy}_{0.2 \%}$ & 59 & 98 & 0.14 & 0.083 & 2.77 & 3.95 & 32.3 & 22.5 & 2.1 & 1.8 \\
\hline $\mathrm{Na}_{2} \mathrm{SO}_{4}: \mathrm{Li}_{0.5 \%}, \mathrm{Eu}_{0.5 \%}, \mathrm{Dy}_{0.5 \%}$ & 39 & 82 & 0.21 & 0.100 & 2.77 & 3.95 & 32.3 & 22.5 & 1.5 & 2.2 \\
\hline
\end{tabular}

$\mathrm{T}$ and $\mathrm{M}$ correspond to thenardite and mirabilite content of $\mathrm{Na}_{2} \mathrm{SO}_{4}$.

detail. The host matrix shows the existence of bicrystalline phase after codoping with hypervalent ion. The codoped and pure $\mathrm{Na}_{2} \mathrm{SO}_{4}$ samples have been well characterized by powder X-ray diffraction (PXRD), scanning electron microscopy (SEM), and transmission electron microscopy (TEM) techniques.

\section{Experimental}

2.1. Materials Preparation. $\mathrm{Na}_{2} \mathrm{SO}_{4}$ and $\mathrm{Li}_{2} \mathrm{SO}_{4}$ (0.5 mol\%) were stoichiometrically dissolved in double-distilled deionized water (A). A known quantity of $\mathrm{RE}_{2} \mathrm{O}_{3}(\mathrm{RE}=\mathrm{Eu}$ and Dy) was dissolved in concentrated $\mathrm{H}_{2} \mathrm{SO}_{4}(\mathrm{~B})$ and added to solution (A) to get $\mathrm{RE} / \mathrm{Na}$ mole ratio in the concentration range of 0.08 to $0.5 \mathrm{~mol} \%$. The solution is then dried in an oven. The sample thus obtained in powder form was crushed and calcined at $400^{\circ} \mathrm{C}$ for $4 \mathrm{~h}$ in furnace. After natural cooling to RT, it is crushed to fine powder and pressed into pellets $\left(80 \mathrm{~kg} / \mathrm{cm}^{2}\right)$.

2.2. Material Characterization. The PXRD pattern of sample is obtained using Philips PW/1050/70/76 X-ray diffractometer which was operated at $30 \mathrm{KV}$ and $20 \mathrm{~mA}$ using $\mathrm{CuK}_{\alpha}$ radiation as the source with a nickel filter at a scan rate of $2 \% \mathrm{~min}$. The size, shape, and distribution of the grains were examined by SEM analysis using Quanta 200 FEI SEM. TEM measurement was carried out using a Philips CM 200 microscope having $2.4 \AA$ resolutions.

TL glow curves were measured with system in the temperature range from 25 to $300^{\circ} \mathrm{C}$ operating with linear heating rates of $5 \mathrm{~K} \mathrm{~s}^{-1}$. Prior to the TL measurements, samples (pellets of $1 \mathrm{~mm}$ thickness with $5 \mathrm{~mm}$ in diameter are used for TL measurements) were exposed to $\gamma$ irradiation from a ${ }^{60} \mathrm{Co}$ source to a total dose of 0.02 to $2 \mathrm{kGy}$ at the sample cavity. Photoluminescence emission and excitation spectra were registered in identical experimental conditions, using Yvon Fluorometer, Jobspectrometer with Xenon lamp source at an excitation wavelength of $340 \mathrm{~nm}$ at SAIF, IIT, Chennai, India.

\section{Results and Discussion}

3.1. Powder X-ray Diffraction Analysis. Figure 1 shows the PXRD of $\mathrm{Na}_{2} \mathrm{SO}_{4}, \mathrm{Na}_{2} \mathrm{SO}_{4}: \mathrm{Li}_{0.5 \%}$, and $\mathrm{Na}_{2} \mathrm{SO}_{4}: \mathrm{Li}_{0.5 \%}$, $\mathrm{Eu}_{0.5 \%}, \mathrm{Dy}_{x \%}(x=0.2,0.5)$. The undoped and $\mathrm{Li}^{+}$-doped $\mathrm{Na}_{2} \mathrm{SO}_{4}$ exhibited stable thenardite, while codoping of $\mathrm{RE}^{3+}$ to $\mathrm{Na}_{2} \mathrm{SO}_{4}$ resulted in the phase transformation from stable

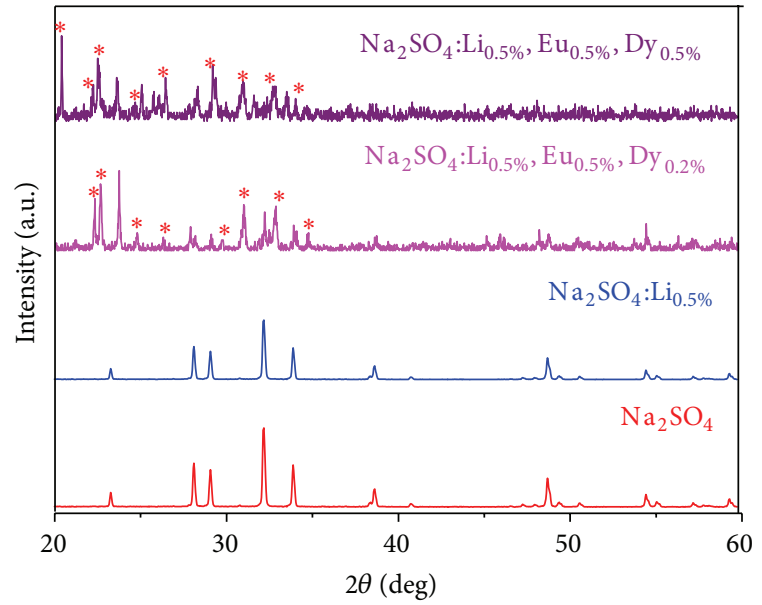

FIGURE 1: Comparison of PXRD patterns of $\mathrm{Na}_{2} \mathrm{SO}_{4}, \mathrm{Na}_{2} \mathrm{SO}_{4}: \mathrm{Li}^{+}$, and $\mathrm{Na}_{2} \mathrm{SO}_{4}: \mathrm{Li}^{+}, \mathrm{Eu}^{3+}, \mathrm{Dy}^{3+}$ with host matrix. (The peaks with asterisks correspond to the mirabilite phase.)

thenardite to metastable mirabilite phase. The mirabilite content in the sample showed critical dependence on $\mathrm{RE}^{3+}$ concentration.

The average crystallite size $(D)$ and matrix distortion $(\varepsilon)$ are calculated from FWHM of the most intense PXRD peak using the following, respectively $[18,19]$ :

$$
\begin{aligned}
& D=\frac{0.9 \lambda}{\beta \cos \theta}, \\
& \beta=4 \varepsilon \tan \theta,
\end{aligned}
$$

where " $D$ " is the average grain size of the crystallites, " $\lambda$ " is the incident wavelength, " $\theta$ " is the Bragg angle, " $\varepsilon$ " is the stress factor, and " $\beta$ " is the diffracted full width at half maximum (in radians) caused by the crystallites.

The higher ionic radius of the $\mathrm{RE}^{3+}$ ion can possibly act as an interstitial impurity in the host matrix. The introduction of substitutional dopant metal ions with a higher ionic size would induce cationic vacancies at the surface of thenardite grains, which favours the bond rupture, ionic rearrangement, and structure reorganization for the formation of mirabilite phase. The thenardite to mirabilite phase is generally considered as a nucleation growth process during which the mirabilite nuclei are formed within the thenardite phase. The thenardite grain size decreases with an increase in the $\mathrm{Dy}^{3+}$ concentration (Table 1). 
TABLE 2: Comparison of lattice parameters and cell volume of pure, Li-doped, and $\mathrm{RE}^{3+}$-codoped $\mathrm{Na}_{2} \mathrm{SO}_{4}$ samples.

\begin{tabular}{lcccccccc}
\hline Phosphor & \multicolumn{2}{c}{$a(\AA)$} & & $b(\AA)$ & & $c(\AA)$ & & \\
& $\mathrm{T}$ & $\mathrm{M}$ & $\mathrm{T}$ & $\mathrm{M}(\AA)^{3}$ & $\mathrm{~T}$ & $\mathrm{M}$ & $\mathrm{M}$ \\
\hline $\mathrm{Na}_{2} \mathrm{SO}_{4}$ & 5.80 & - & 12.20 & - & 7.60 & - & 538 \\
$\mathrm{Na}_{2} \mathrm{SO}_{4}: \mathrm{Li}_{0.5 \%}$ & 5.86 & - & 12.32 & - & 7.66 & - & 553 & - \\
$\mathrm{Na}_{2} \mathrm{SO}_{4}: \mathrm{Li}_{0.5 \%}, \mathrm{Eu}_{0.5 \%}, \mathrm{Dy}_{0.2 \%}$ & 10.7 & 9.51 & 10.43 & 15.6 & 6.08 & 3.452 & 679 & 512 \\
$\mathrm{Na}_{2} \mathrm{SO}_{4}: \mathrm{Li}_{0.5 \%}, \mathrm{Eu}_{0.5 \%}, \mathrm{Dy}_{0.5 \%}$ & 11.0 & 9.55 & 10.47 & 15.8 & 6.12 & 3.481 & 705 & 525 \\
\hline
\end{tabular}

$\mathrm{T}$ and $\mathrm{M}$ correspond to thenardite and mirabilite content of $\mathrm{Na}_{2} \mathrm{SO}_{4}$.

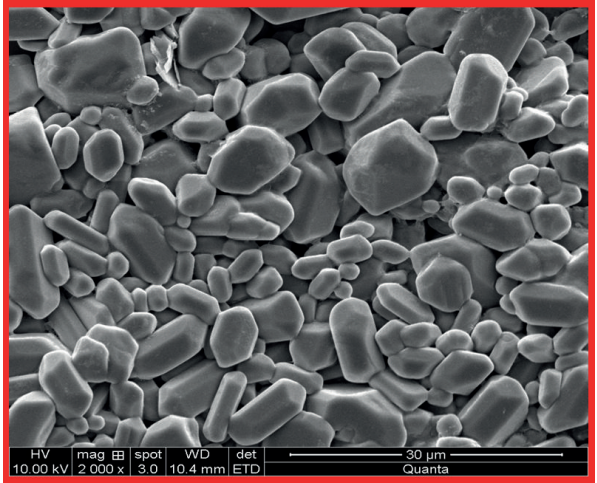

(a)

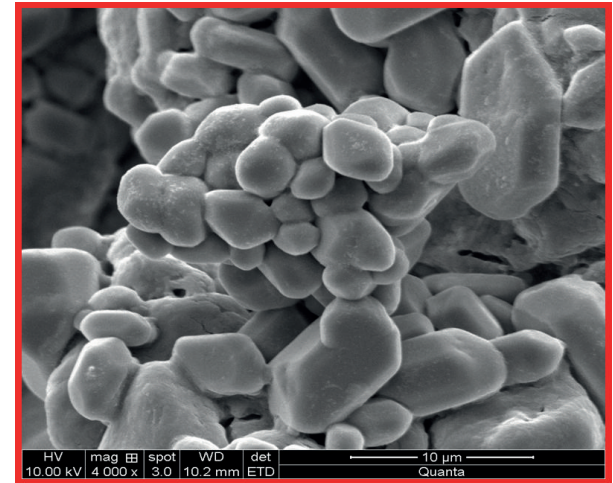

(b)

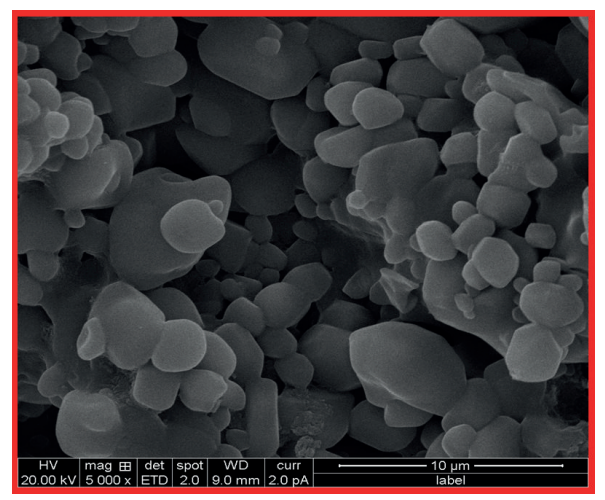

(c)

FIgURE 2: SEM image of (a) $\mathrm{Na}_{2} \mathrm{SO}_{4}$, (b) $\mathrm{Na}_{2} \mathrm{SO}_{4}$ : $\mathrm{Li}$, and (c) $\mathrm{Na}_{2} \mathrm{SO}_{4}$ : $\mathrm{Li}$, Eu, Dy, respectively.

With an increase in the $\mathrm{Dy}^{3+}$ content, the variation in the lattice parameter was reflected in the elongation of the $c$ axis (Table 2). Since only thecdimension changes while $a$-axis and $b$-axis remain almost constant for the range of dopant concentration, it can be concluded that with increase in $\mathrm{Dy}^{3+}$ concentration the crystal growth proceeds along $c$-axis. The extent of matrix distortion was nearly $\sim 200$ times higher for doped samples compared to bare samples due to the higher ionic radius of $\mathrm{RE}^{3+}$ compared to host $\mathrm{Na}^{+}$. It is well known that the incorporation of $\mathrm{RE}^{3+}$ ions within the host crystal introduces lattice strains as a result of size mis match.

Due to smaller ionic radius, the stress associated with $\mathrm{Li}^{+}$is dominated by lattice contraction. It is interesting to note that stress factor associated with $\mathrm{Li}^{+}$doping (lattice contraction) is larger compared to $\mathrm{RE}^{3+}$ doping (lattice expansion).
3.2. Scanning Electron Microscopy Studies. The surface morphological features of the $\mathrm{Na}_{2} \mathrm{SO}_{4}, \mathrm{Na}_{2} \mathrm{SO}_{4}: \mathrm{Li}_{0.5 \%}$, and $\mathrm{Na}_{2} \mathrm{SO}_{4}: \mathrm{Li}_{0.5 \%}, \mathrm{Eu}_{0.5 \%}, \mathrm{Dy}_{0.5 \%}$ samples are shown in Figure 2. The pure, $\mathrm{Li}^{+}$-doped, and $\mathrm{RE}^{3+}$-codoped $\mathrm{Na}_{2} \mathrm{SO}_{4}$ showed the uniform distribution of generalized hexagonal habit of grains corresponding to orthorhombic prisms and pyramids without any agglomeration. The codoping leads to noticeable changes on the grain size of the sample.

3.3. Transmission Electron Microscopy Studies. The shape and size of these particles were also determined by TEM (Figures 3 and 4). TEM images and selected area electron diffraction (SAED) of $\mathrm{Na}_{2} \mathrm{SO}_{4}$ and $\mathrm{Na}_{2} \mathrm{SO}_{4}: \mathrm{Li}_{0.5 \%}$ showed that the crystals are hexagonal-shaped particles with almost no amorphous constituents and are weekly aggregated. SAED patterns of these samples were neither regular diffraction 


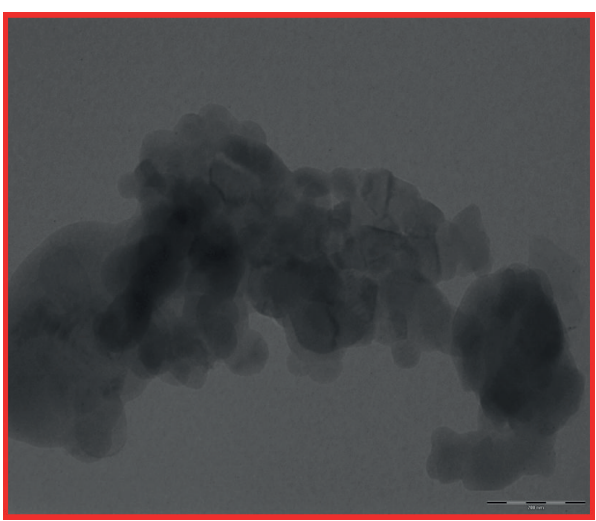

(a)

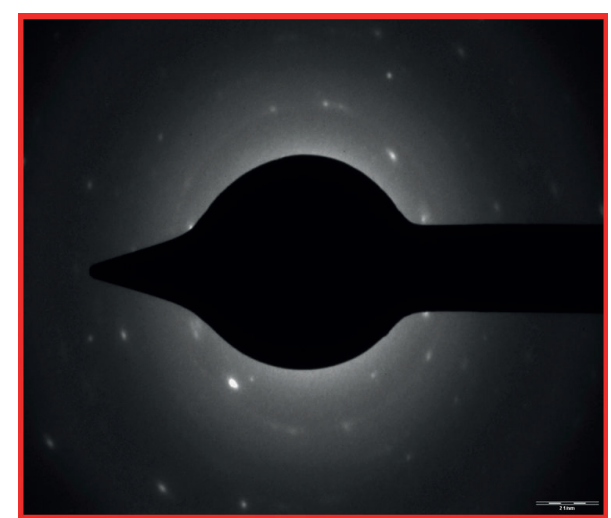

(b)

Figure 3: (a) TEM image and (b) selected area electron diffractions of $\mathrm{Na}_{2} \mathrm{SO}_{4}$.

spots nor whole diffraction rings, indicating that the number of polycrystalline grains in the selected area was finite.

Results revealed that, in pure $\mathrm{Na}_{2} \mathrm{SO}_{4}$, these spots might belong to the $d$-values of $3.636,3.18,3.07$, and $2.78 \AA$ which corresponds to (200), (131), (040), and (311) planes of thenardite. In $\mathrm{Na}_{2} \mathrm{SO}_{4}: \mathrm{Li}^{+}, \mathrm{Eu}^{3+}, \mathrm{Dy}^{3+}$ these spots correspond to $d$-values $4.166,3.77,2.85$, and $2.01 \AA$ which correspond to (112), (220), (-402), and (151) planes. Among them (220) and (151) belong to thenardite and (112) and $(-402)$ belong to mirabilite content of $\mathrm{Na}_{2} \mathrm{SO}_{4}$.

\subsection{Thermoluminescence Studies}

3.4.1. TL Studies of $\mathrm{Na}_{2} \mathrm{SO}_{4}$ and $\mathrm{Na}_{2} \mathrm{SO}_{4}: \mathrm{Li}^{+}$. TL property of host sample was investigated at different $\gamma$-ray dose levels. The pristine orthorhombic phosphor has only one glow main peak at $\sim 180^{\circ} \mathrm{C}$. The intensity of these glow peaks increases with irradiation and shifts towards higher temperature region (Figure 5).

In $\mathrm{Na}_{2} \mathrm{SO}_{4}: \mathrm{Li}_{0.5 \%}, \mathrm{Li}^{+}$quenches the $\mathrm{TL}$ intensity of $\mathrm{Na}_{2} \mathrm{SO}_{4}$ and shifts the TL glow curves position towards lower temperature (Figure 6).

3.4.2. TL Studies of $\mathrm{Na}_{2} \mathrm{SO}_{4}: \mathrm{Li}^{+}, \mathrm{Eu}^{3+}, \mathrm{D} y^{3+}$. The glow curve of $\mathrm{Na}_{2} \mathrm{SO}_{4}: \mathrm{Li}_{0.5 \%}^{+}, \mathrm{Eu}_{0.5 \%}^{3+}, \mathrm{Dy}_{0.5 \%}^{3+}$ consists of a single glow peak ranging from 382 to $424 \mathrm{~K}$ (Figure 7). The TL intensity increases with increase in the $\gamma$-ray exposure and lies between that of $\mathrm{Na}_{2} \mathrm{SO}_{4}: \mathrm{Li}_{0.5 \%}^{+}, \mathrm{Eu}_{0.5 \%}^{3+}$ and that of $\mathrm{Na}_{2} \mathrm{SO}_{4}: \mathrm{Li}_{0.5 \%}^{+}$, $\mathrm{Dy}_{0.5 \%}^{3+}$. This suggests that an increasing number of traps responsible for these glow peaks were getting filled with an increase in radiation dose. These traps release the charge carriers on thermal stimulation to finally recombine with their counterparts, thus giving rise to different glow peaks. However, the TL intensity still remains higher compared to host sample.

3.4.3. Calculation of Kinetic Parameters. The trap parameters, such as activation energy $E$ and order of kinetics $b$, were calculated for the different concentration TL glow peak of the
$\mathrm{Na}_{2} \mathrm{SO}_{4}: \mathrm{Li}_{0.5 \%}$ and $\mathrm{Na}_{2} \mathrm{SO}_{4}: \mathrm{Li}_{0.5 \%}, \mathrm{Eu}_{x \%}, \mathrm{Dy}_{x \%}(x=0.1,0.2$, and 0.5$)$ phosphor irradiated with a gamma dose of $2 \mathrm{kGy}$ at RT using Chen's set of empirical formulae for the shape of glow curve (Figure 8) [20].

In the present study, geometrical form factor value is very close to 0.52 , suggesting that the TL emission involves retrapping of charges. Table 3 lists the peak parameters as obtained for deconvoluted peaks for different $\mathrm{RE}^{3+}$ concentration

$$
E_{\alpha}=C_{\alpha}\left(\frac{k T_{m}^{2}}{\alpha}\right)-b_{\alpha}\left(2 k T_{m}\right),
$$

where $\alpha=\omega, \tau, \delta, \omega=T_{2}-T_{1}, \delta=T_{2}-T_{m}, \tau=T_{m}-T_{1}$,

$$
\begin{gathered}
C_{\tau}=1.51+3.0\left(\mu_{g}-0.42\right) ; \\
b_{\tau}=1.58+4.2\left(\mu_{g}-0.42\right), \\
C_{\delta}=0.976+7.3\left(\mu_{g}-0.42\right) ; \quad b_{\delta}=0, \\
C_{\omega}=2.52+10.2\left(\mu_{g}-0.42\right) ; \quad b_{\omega}=1, \\
\mu_{g}=\frac{T_{2}-T_{m}}{T_{2}-T_{1}}, \\
s=\left(\frac{\beta E}{k T_{m}^{2}}\right)\left(\frac{\exp \left(E / k T_{m}\right)}{1+(b-1)\left(2 k T_{m} / E\right)}\right),
\end{gathered}
$$

where $k$ is the Boltzmann constant $=8.6 \times 10^{-5} \mathrm{eVK}^{-1}$.

3.4.4. TL Fading. The effect of fading was studied up to 90 days by irradiating samples with a gamma dose of $2 \mathrm{kGy}$. The extent of fading was maximum for $\mathrm{Na}_{2} \mathrm{SO}_{4}$ compared to codoped $\mathrm{Na}_{2} \mathrm{SO}_{4}$, suggesting that introduced by addition trap sites favouring the intensification of TL signal (Figure 9). About $1.4 \%, 1.16 \%$, and $1.19 \%$ of fading were observed for $\mathrm{Na}_{2} \mathrm{SO}_{4}, \mathrm{Na}_{2} \mathrm{SO}_{4}: \mathrm{Li}_{0.5 \%}$, and $\mathrm{Na}_{2} \mathrm{SO}_{4}: \mathrm{Li}_{0.5 \%}, \mathrm{Eu}_{0.5 \%}, \mathrm{Dy}_{0.5 \%}$, respectively, during the first five days, but thereafter the intensity remained almost constant up to 20 days; afterwards fading becomes maximum. However, it is suggested that the irradiation of nanocrystalline phosphor at high doses results in the formation of deep traps which resulted in the fading of TL signal. 


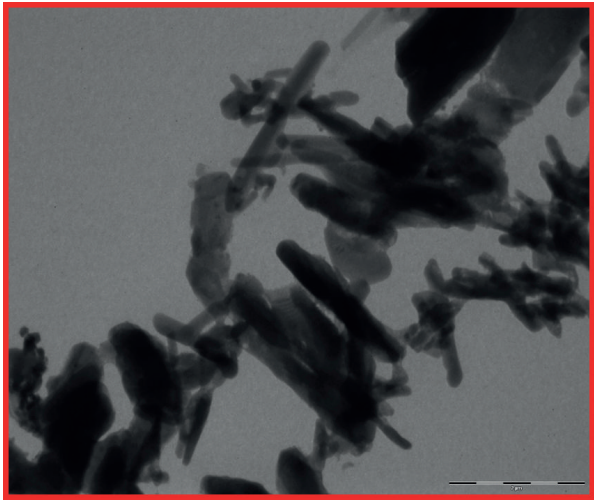

(a)

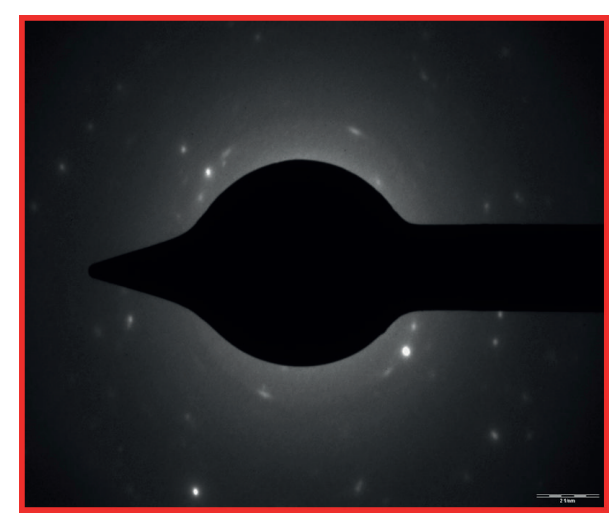

(b)

FIgURE 4: (a) TEM images and (b) selected area electron diffraction of $\mathrm{Na}_{2} \mathrm{SO}_{4}$ : $\mathrm{Li}, \mathrm{Eu}, \mathrm{Dy}$.

TABLE 3: Comparison of kinetic parameters for pure, Li-doped, and $\mathrm{RE}^{3+}$-codoped $\mathrm{Na}_{2} \mathrm{SO}_{4}$ samples.

\begin{tabular}{lcc}
\hline Phosphor & $\begin{array}{c}\text { Activation } \\
\text { energy }(\mathrm{eV})\end{array}$ & $\begin{array}{c}\text { Frequency factor } \\
\left(\mathrm{s}^{-1}\right)\end{array}$ \\
\hline $\mathrm{Na}_{2} \mathrm{SO}_{4}$ & 0.15 & $4.59 \times 10^{9}$ \\
$\mathrm{Na}_{2} \mathrm{SO}_{4}: \mathrm{Li}_{0.5 \%}$ & 0.35 & $5.51 \times 10^{13}$ \\
$\mathrm{Na}_{2} \mathrm{SO}_{4}: \mathrm{Li}_{0.5 \%}, \mathrm{Eu}_{0.5 \%}$, & 0.18 & $1.41 \times 10^{11}$ \\
$\mathrm{Dy}_{0.1 \%}$ & & \\
$\mathrm{Na}_{2} \mathrm{SO}_{4}: \mathrm{Li}_{0.5 \%}, \mathrm{Eu}_{0.5 \%}$, & 0.19 & $1.20 \times 10^{11}$ \\
$\mathrm{Dy}_{0.2 \%}$ & & \\
$\mathrm{Na}_{2} \mathrm{SO}_{4}: \mathrm{Li}_{0.5 \%}, \mathrm{Eu}_{0.5 \%}$, & 0.20 & $1.51 \times 10^{12}$ \\
$\mathrm{Dy}_{0.5 \%}$ & & \\
\hline
\end{tabular}

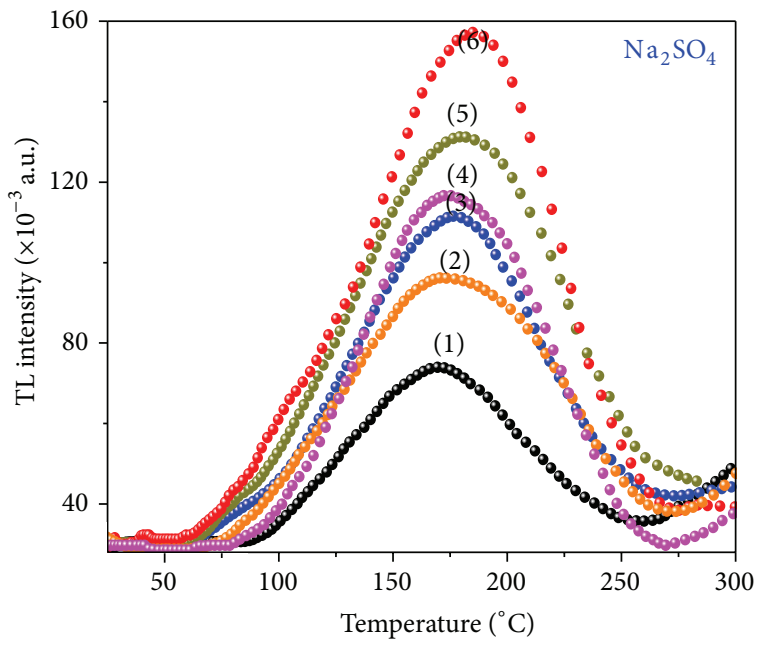
(1): $0.2 \mathrm{kGy}$
(4): $3.0 \mathrm{kGy}$
(2): $1.0 \mathrm{kGy}$
(5): $3.5 \mathrm{kGy}$
(3): $2.0 \mathrm{kGy}$
(6): $4.0 \mathrm{kGy}$

FIGURE 5: TL glow curves of $\gamma$-irradiated $\mathrm{Na}_{2} \mathrm{SO}_{4}$ calcined at $400^{\circ} \mathrm{C}$.

\subsection{Photoluminescence Studies}

3.5.1. PL Studies of $\mathrm{Na}_{2} \mathrm{SO}_{4}$ and $\mathrm{Na}_{2} \mathrm{SO}_{4}: \mathrm{Li}^{+}$. The PL emission spectra of host sample consist of a strong peak at $364 \mathrm{~nm}$

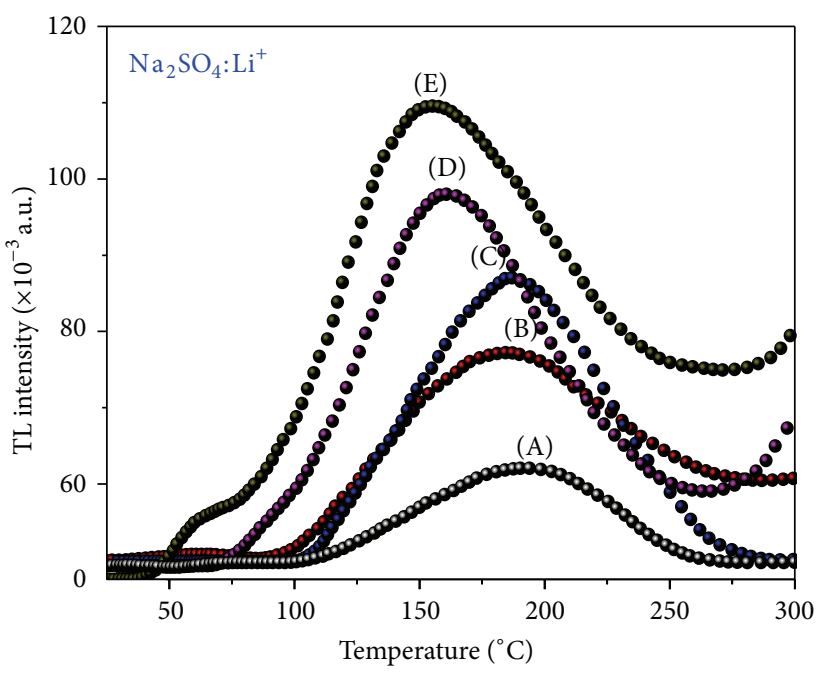
(A): $0.5 \mathrm{kGy}$
(D): $3.0 \mathrm{kGy}$
(B): $1.0 \mathrm{kGy}$
(E): $4.0 \mathrm{kGy}$
(C): $2.0 \mathrm{kGy}$

FIGURE 6: TL glow curves of $\gamma$-irradiated $\mathrm{Na}_{2} \mathrm{SO}_{4}$ : $\mathrm{Li} 0.5 \%$ calcined at $400^{\circ} \mathrm{C}$.

for pure thenardite and are attributed to band-to-band PL phenomenon due to the band gap excitation (Figure 10).

In addition, low intense peak at $\sim 702 \mathrm{~nm}$ is attributed to excitonic PL arising from intrinsic defects of thenardite $\mathrm{Na}_{2} \mathrm{SO}_{4}$ powders. The emission band with the most intense peak at approximately $702 \mathrm{~nm}$ showed a distinct vibronic structure. The vibronic structure characteristic of $S^{2-}$ centre was observed in the red region.

The $\gamma$-ray irradiated thenardite did not change the feature of PL but reduced the luminescence efficiency. This suggests that $\gamma$-ray irradiation of thenardite may generate a killer centre for luminescence in thenardite. We could not find any dip due to absorption by the killer centre. It seems that $\gamma$-ray irradiation has an annealing effect although mechanism was not yet clear. 


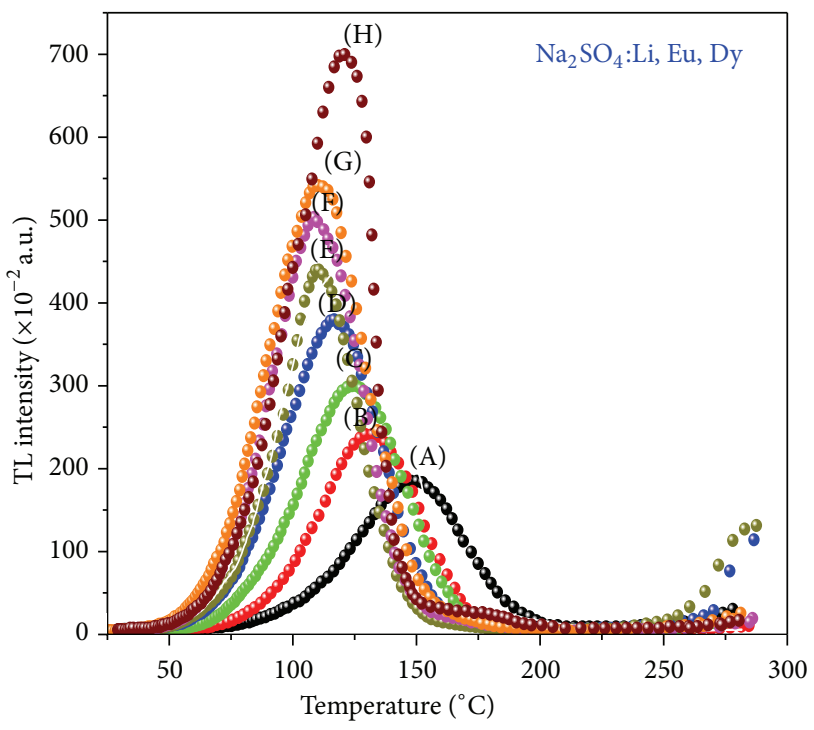
(A): $0.5 \mathrm{kGy}$
(E): $2.5 \mathrm{kGy}$
(B): $1.0 \mathrm{kGy}$
(F): $3.0 \mathrm{kGy}$
(C): $1.5 \mathrm{kGy}$
(D): $2.0 \mathrm{kGy}$
(G): $4.0 \mathrm{kGy}$
(H): $5.0 \mathrm{kGy}$

Figure 7: TL glow curves of $\gamma$-irradiated $\mathrm{Na}_{2} \mathrm{SO}_{4}$ : $\mathrm{Li}, \mathrm{Eu}, \mathrm{Dy}$ calcined at $400^{\circ} \mathrm{C}$.

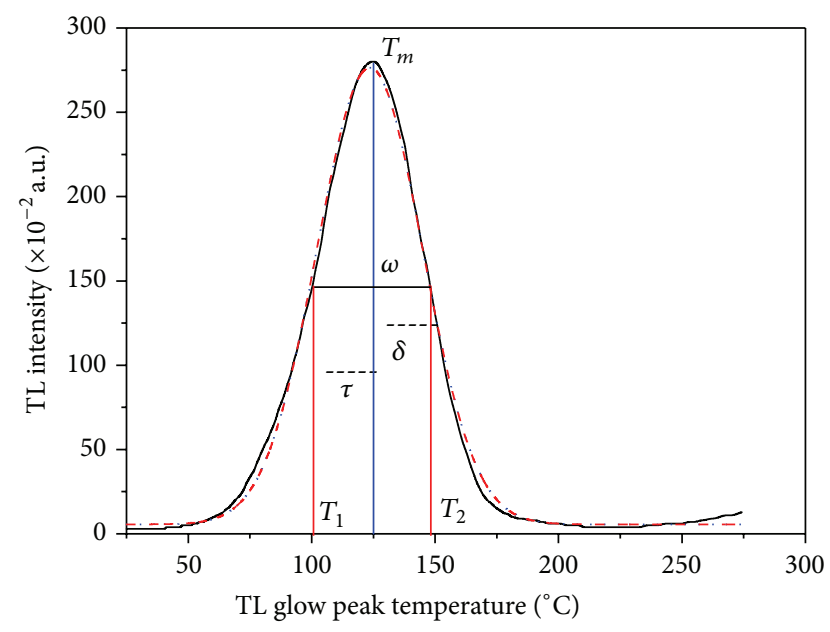

FIGURE 8: Representative diagram of different quantities used in the glow curve shape method.

The PL emission spectra of $\mathrm{Na}_{2} \mathrm{SO}_{4}: \mathrm{Li}_{0.5 \%}$ are the same as that of the host sample (Figure 11).

3.5.2. PL Studies of $\mathrm{Na}_{2} \mathrm{SO}_{4}: \mathrm{Li}^{+}, \mathrm{Eu}^{3+}$. The PL emission spectra of $\mathrm{Na}_{2} \mathrm{SO}_{4}: \mathrm{Li}^{+}, \mathrm{Eu}^{3+}, \mathrm{Dy}^{3+}$ for $340 \mathrm{~nm}$ excitation showed bands at 481, 490,575, and $711 \mathrm{~nm}$. The first three peaks are assigned to $\mathrm{Dy}^{3+}$ and the peak arising at $711 \mathrm{~nm}$ was assigned to $\mathrm{Eu}^{3+}$ emission (Figure 12).

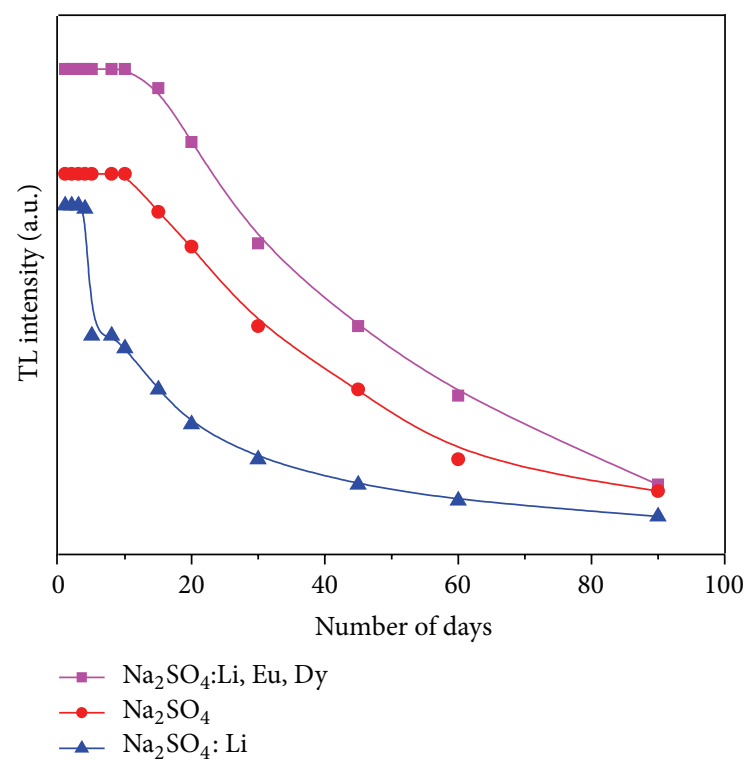

FIGURE 9: Fading observed in $\mathrm{Na}_{2} \mathrm{SO}_{4}, \mathrm{Na}_{2} \mathrm{SO}_{4}: \mathrm{Li}_{0.5 \%}$, and $\mathrm{Na}_{2} \mathrm{SO}_{4}$ : $\mathrm{Li}_{0.5 \%} \mathrm{Eu}_{0.5 \%}, \mathrm{Dy}_{0.5 \%}$.

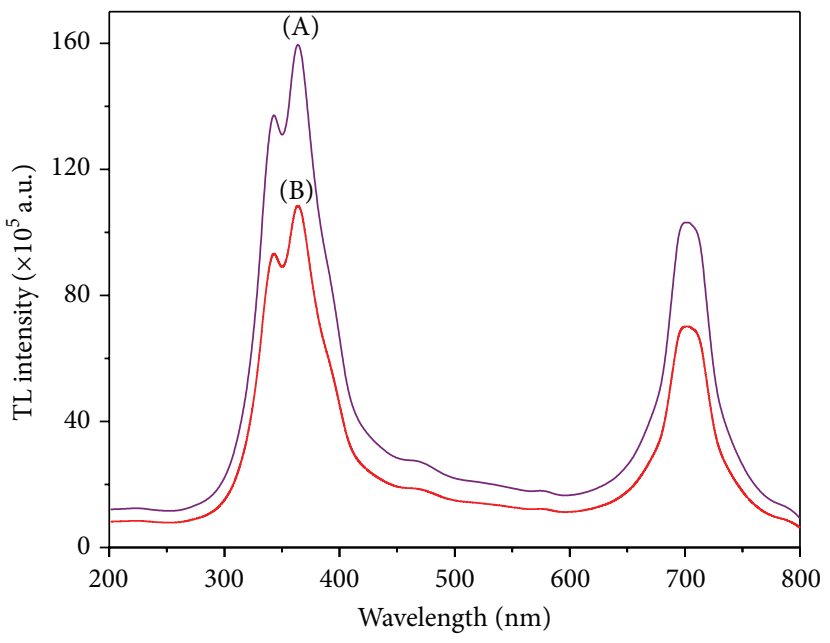

(A) Unirradiated $\mathrm{Na}_{2} \mathrm{SO}_{4}$

(B) $\gamma$-ray irradiated $\mathrm{Na}_{2} \mathrm{SO}_{4}$

FIGURE 10: PL emission spectra of pure $\mathrm{Na}_{2} \mathrm{SO}_{4}\left(\lambda_{\text {ex }}=340 \mathrm{~nm}\right)$.

\section{Conclusions}

Pure and codoped phosphors have been prepared at RT by slow evaporation technique. PXRD pattern confirmed the phase transformation from stable thenardite to metastable mirabilite after codoping with $\mathrm{RE}^{3+}$ ions. SEM studies showed the presence of uniform distribution of prisms and pyramids. The codopant introduces additional trap sites favouring the intensification of TL signal. Therefore, up to a given irradiation dose, this phosphor has potential candidate for use in radiation dosimetry. The PL intensities of codoped $\mathrm{Na}_{2} \mathrm{SO}_{4}$ samples were found to be dependent on the $\mathrm{RE}^{3+}$ concentration. 


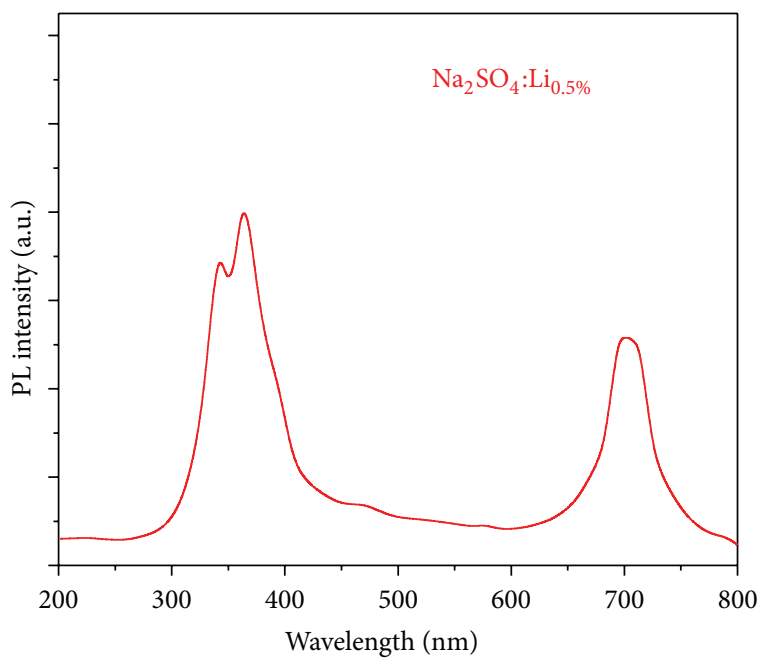

Figure 11: PL emission spectra of $\mathrm{Na}_{2} \mathrm{SO}_{4}: \mathrm{Li}\left(\lambda_{\mathrm{ex}}=340 \mathrm{~nm}\right)$.

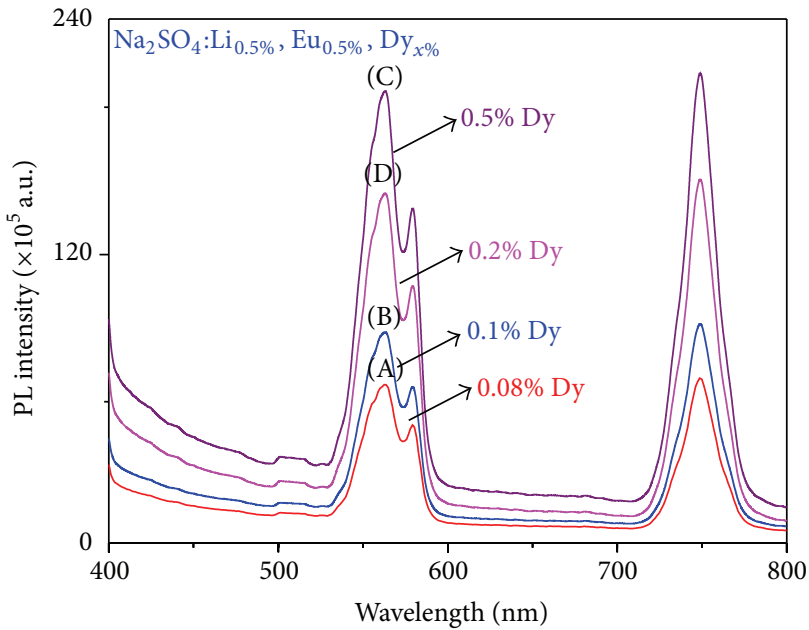

Figure 12: PL emission spectra of $\mathrm{Na}_{2} \mathrm{SO}_{4}: \mathrm{Li}_{0.5 \%}, \mathrm{Eu}_{0.5 \%}$, $\operatorname{Dy}_{0.5 \%}\left(\lambda_{\mathrm{ex}}=340 \mathrm{~nm}\right)$.

\section{Conflict of Interests}

The authors declare that there is no conflict of interests regarding the publication of this paper.

\section{Acknowledgments}

Y. S. Vidya is thankful to "ISRO-ISEC, advanced devices and radiation cell, Bangalore" for providing facilities for $\gamma$ irradiation. The author also wishes to thank Dr. S. Girish Kumar, PDF Scholar, Department of Physics, IISc, Bangalore, and Department of Physics, Lal Bahadur Shastri Government First Grade College, R. T. Nagar, Bangalore, for their support.

\section{References}

[1] R. S. Kher, A. K. Upadhyay, S. J. Dhoble, and M. S. K. Khokhar, "Luminescence studies of $\mathrm{MgSO}_{4}$ Dy phosphors," Indian Journal of Pure and Applied Physics, vol. 46, no. 9, pp. 607-610, 2008.

[2] A. K. Panigrahi, S. J. Dhoble, R. S. Kher, and S. V. Moharil, "Thermo and mechanoluminescence of $\mathrm{Dy}^{3+}$ activated $\mathrm{K}_{2} \mathrm{Mg}_{2}\left(\mathrm{SO}_{4}\right)_{3}$ phosphor," Physica Status Solidi A, vol. 198, no. 2, pp. 322-328, 2003.

[3] C.-X. Zhang, P. L. Leung, Q. Tang, D.-L. Luo, and M. J. Stokes, "Spectral comparison of $\mathrm{MgSO}_{4}$ doped with $\mathrm{Dy}, \mathrm{Mn}, \mathrm{P}$, and Cu," Journal of Physics D, vol. 34, no. 10, pp. 1533-1539, 2001.

[4] T. K. Gundu Rao, B. C. Bhatt, J. K. Srivastava, and K. S. V. Nambi, "On the sulphoxy radicals in $\mathrm{CaSO}_{4}: \mathrm{Dy}, \mathrm{Na}$ thermoluminescent phosphor: electron paramagnetic resonance studies," Journal of Physics: Condensed Matter, vol. 5, no. 12, pp. 1791-1800, 1993.

[5] S. J. Dhoble, S. V. Moharil, and T. K. G. Rao, "Correlated ESR, $\mathrm{PL}$ and TL studies on $\mathrm{K}_{3} \mathrm{Na}\left(\mathrm{SO}_{4}\right)_{2}$ : Eu thermoluminescence dosimetry phosphor," Journal of Luminescence, vol. 93, no. 1, pp. 43-49, 2001.

[6] S. C. Gedam, "Thermoluminescence (TL) study of $\mathrm{CeSO}_{4} \mathrm{Cl}$ : Dy phosphor for $\gamma$-radiation dosimetry," Research Journal of Engineering Sciences, vol. 2, pp. 28-31, 2013.

[7] M. Magarabi, A. A. Finch, and P. D. Townsend, "Structural and impurity phase transitions of $\mathrm{LiNaSO}_{4}$ : $\mathrm{RE}$ probed using cathodo-thermoluminescence," Journal of Physics: Condensed Matter, vol. 43, pp. 776-780, 2008.

[8] A. Vij, S. P. Lochab, S. Singh, R. kumar, and N. Singh, "Thermoluminescence study of UV irradiated Ce doped SrS nanostructures," Journal of Alloys and Compounds, vol. 486, no. 1-2, pp. 554-558, 2009.

[9] J. P. Elder, "Thermal energy storage materials a DSC study," Thermochimica Acta, vol. 36, no. 1, pp. 67-77, 1980.

[10] H. G. Wiedemann, "Thermal studies on thenardite," Thermochimica Acta, vol. 50, pp. 17-29, 1981.

[11] O. Braitsh and K. S. D. Entstehung, Salzlagerstallen, Springer, New York, NY, USA, 1962.

[12] S. Gomathy, P. Gopalan, and A. R. Kulkarni, "Effect of homovalent anion doping on the conductivity and phase transitions in $\mathrm{Na}_{2} \mathrm{SO}_{4}$," Journal of Solid State Chemistry, vol. 146, no. 1, pp. 6$12,1999$.

[13] F. C. Kracek and R. E. Gibson, "The polymorphism of sodium sulfate: III. Dilatometer investigations," Journal of Physical Chemistry, vol. 34, no. 1, pp. 188-206, 1930.

[14] B. K. Choi, H. K. Lee, and Y. W. Kim, "Ionic conduction and structural phase transitions of $\mathrm{Na}_{2} \mathrm{SO}_{4}$ doped with various impurities," Solid State Ionics, vol. 113, pp. 493-499, 1998.

[15] C. Rodriguez-Navarro, E. Doehne, and E. Sebastian, "How does sodium sulfate crystallize? Implications for the decay and testing of building materials," Cement and Concrete Research, vol. 30, no. 10, pp. 1527-1534, 2000.

[16] V. Correcher, J. Garcia-Guinea, P. Lopez-Arce, and J. M. GomezRos, "Luminescence emission spectra in the temperature range of the structural phase transitions of $\mathrm{Na}_{2} \mathrm{SO}_{4}$," Spectrochimica Acta A, vol. 60, no. 7, pp. 1431-1438, 2004.

[17] A. Sidike, K. Niyazi, H.-J. Zhu, K. Atobe, and N. Yamashita, "Photoluminescence properties of thenardite from Ai-Ding Salt Lake, Xinjiang, China," Physics and Chemistry of Minerals, vol. 36, no. 3, pp. 119-126, 2009.

[18] H.-C. Freiheit, "Order parameter behaviour and thermal hysteresis at the phase transition in the superionic conductor lithium sodium sulfate $\mathrm{LiNaSO}_{4}$," Solid State Communications, vol. 119, no. 8-9, pp. 539-544, 2001.

[19] A. Choubey, S. K. Sharma, S. P. Lochab, and D. Kanjilal, "Effect of ion irradiation on the thermoluminescence properties of 
$\mathrm{K}_{2} \mathrm{Ca}_{2}\left(\mathrm{SO}_{4}\right)_{3}$ phosphor," Radiation Effects and Defects in Solids, vol. 166, no. 7, pp. 487-500, 2011.

[20] R. Chen and Y. Kirish, Analysis of Thermally Stimulated Processes, Pergamon, New York, NY, USA, 1981. 

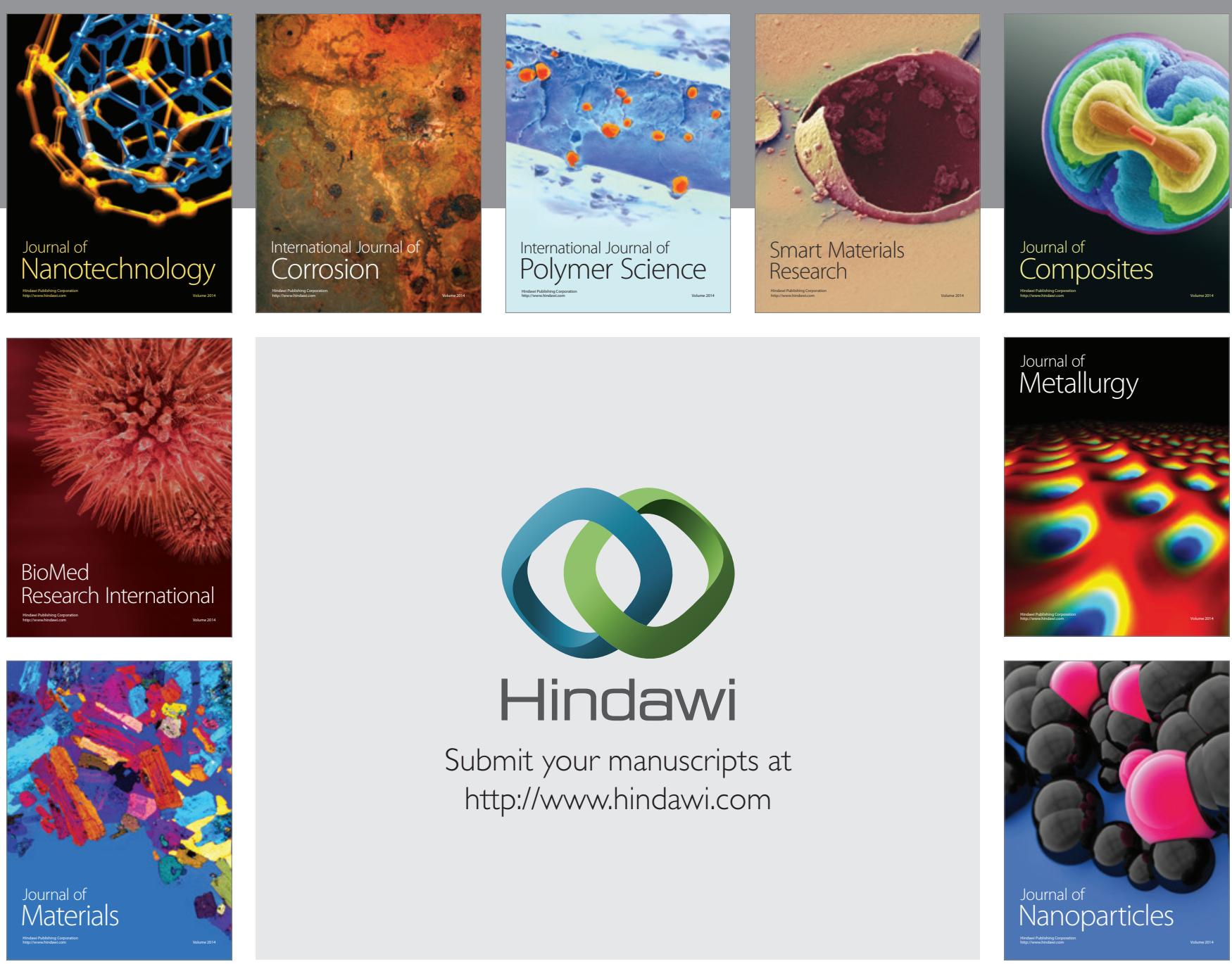

Submit your manuscripts at http://www.hindawi.com
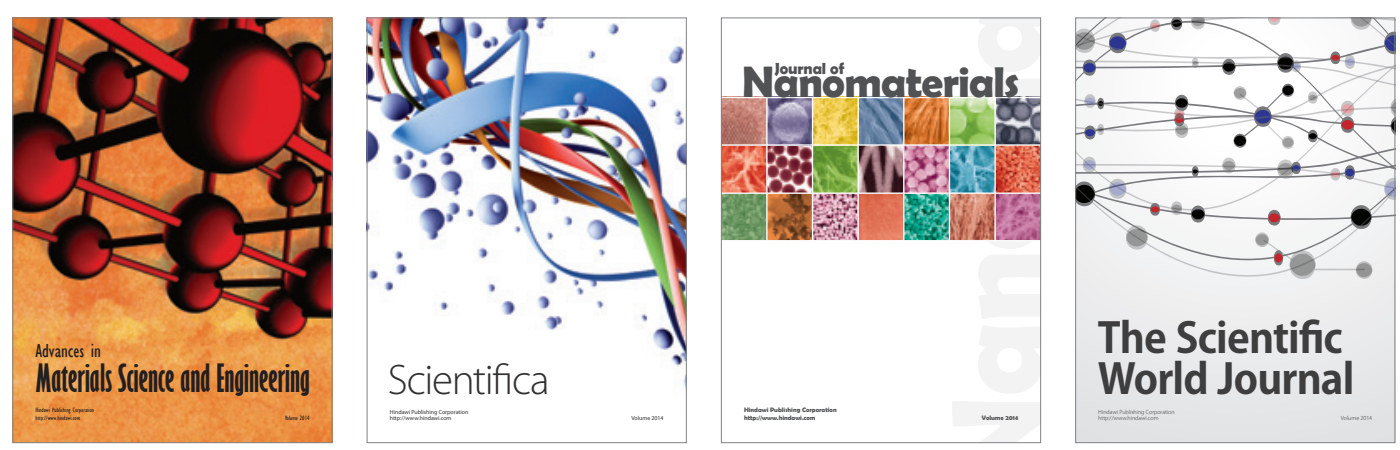

\section{The Scientific World Journal}
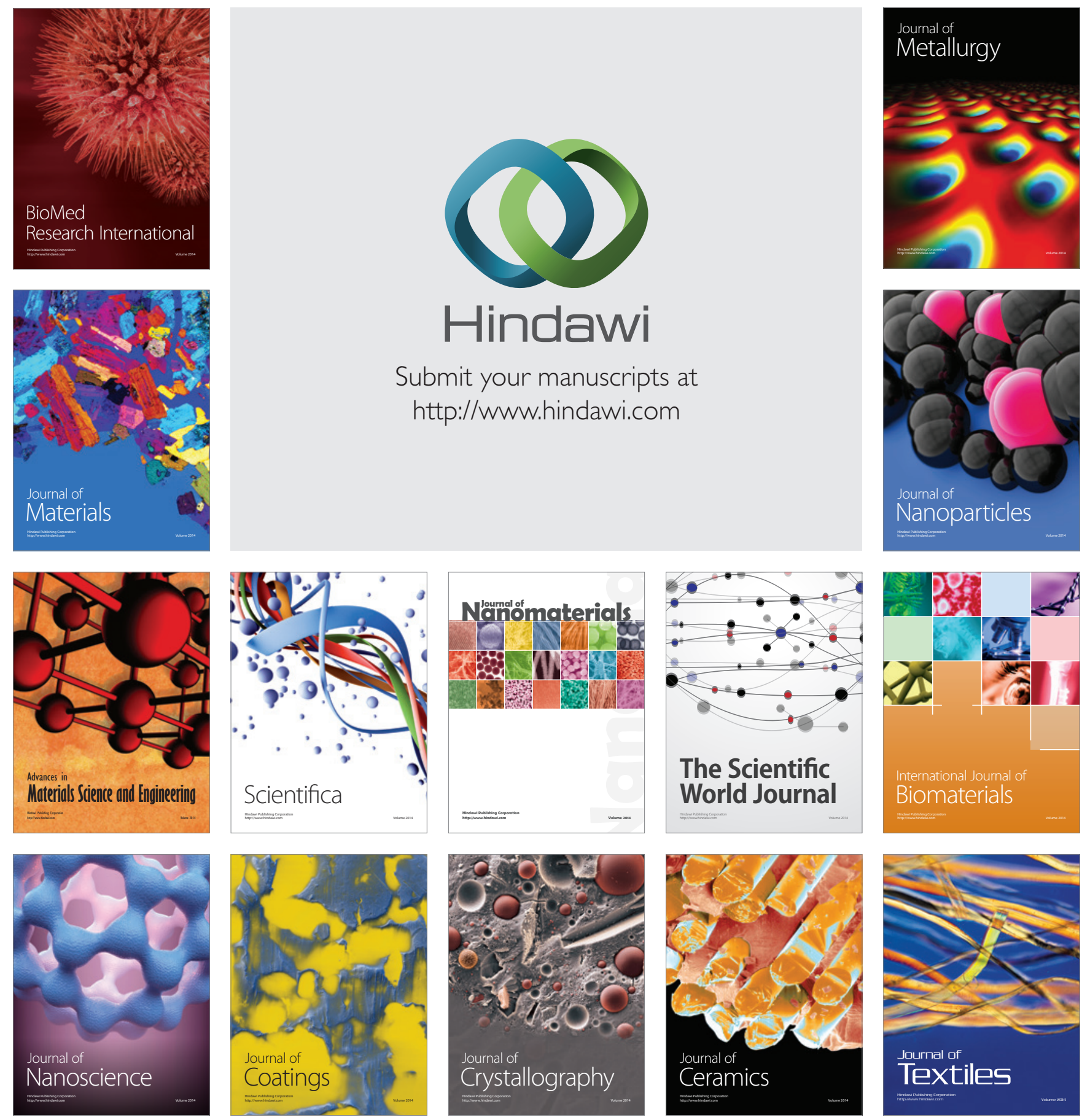